\title{
Efektivitas dan Efisiensi Sistem Informasi Keluarga Berencana di Puskesmas
}

\author{
The Effectiveness and Efficiency of Family Planning Information System in The \\ Health Center
}

\author{
Aragar Putri* Besral ${ }^{* * *}$
}

*Direktorat Bina Kesehatan Ibu Direktorat Jenderal Bina Kesehatan Masyarakat Kementerian Kesehatan RI, **Departemen Biostatistik dan Ilmu Kependudukan Fakultas Kesehatan Masyarakat Universitas Indonesia

\begin{abstract}
Abstrak
Efisiensi dan efektivitas sistem informasi keluarga berencana (KB)-kesehatan yang telah disosialisasikan sejak tahun 2007 dibandingkan dengan sistem yang lama belum diketahui. Suatu penelitian survei dilakukan di empat provinsi, yaitu DKI Jakarta, Lampung, Kalimatan Tengah, dan Bali. Di tiap provinsi dipilih dua kabupaten/kota dan pada tiap kabupaten/kota dipilih dua puskesmas (kecamatan) yang sudah menerapkan sistem informasi KB-kesehatan tersebut. Pengumpulan data dilakukan pada bulan JuniSeptember 2008. Penelitian ini menemukan bahwa efektivitas dan efisiensi sistem informasi KB yang baru cukup baik, $77,8 \%$ responden menyatakan lebih efektif atau sangat lebih efektif dan $66,7 \%$ responden menyatakan lebih efisien atau sangat lebih efisien dibandingkan dengan sistem yang lama. Skor efektivitas dan efisiensi berbeda antar provinsi (nilai $p$ $<0,01$ ), skor terendah di provinsi Bali (rata-rata 68,9 untuk efektivitas dan 61,3 untuk efisiensi), dan skor tertinggi di Kalimantan Tengah (rata-rata 82,7 untuk efektivitas dan 82,2 untuk efisiensi). Tidak ada perbedaan skor efektivitas dan efisiensi sistem informasi KB menurut lingkup kerja dan jabatan responden (nilai $p>0,05$ ). Disarankan kepada Kementerian Kesehatan untuk dapat melakukan perbaikan pada komponen sistem informasi keluarga berencana, terutama dalam pembuatan grafik pemantauan wilayah setempat KB dan mengimplementasikannya di pelayanan KB di puskemas beserta jaringannya.

Kata kunci: Efektivitas, efisiensi, sistem informasi, keluarga berencana
\end{abstract}

Abstract

A study is to know the efficiency and effectiveness of the new family planning information system that has been socialized since 2007. To compare with the previous information system, this study was conducted in four provinces i.e., DKI Jakarta, Lampung, Central Kalimatan, and Bali. In each province two districts were randomly selected, and from each selected district two health centers were then randomly selected. Data was collected from June to September 2008. Results of this study revealed that the ef- fectiveness and efficiency of the new family planning information system is considered good, where $77,8 \%$ of the respondents reported it as effective or more effective, and $66,7 \%$ stated more or much more efficient compared to the previous system. The mean score for effectiveness and efficiency vary between provinces ( $p$-value $<0,01$ ). The lowest score was found in Bali (mean 68,9 for effectiveness and 61,3 for efficiency), and the highest score was in Central Kalimantan (mean 82.7 for effectiveness and 82.2 for efficiency). There is no significant difference of the score according to characteristics of the respondents. This study recommends to improve the family planning information system, especially by providing and implementing the local monitoring graph, in the health center and its network.

Key words: Effectiveness, efficiency, information system, family planning

\section{Pendahuluan}

Program KB di Indonesia telah mampu mencapai hasil yang memuaskan. Kesadaran masyarakat akan pentingnya Norma Keluarga Kecil yang Bahagia dan Sejahtera (NKKBS) dari tahun ke tahun tampak makin meningkat. Sayangnya, krisis ekonomi pada tahun 1997, telah mempengaruhi pelaksanaan program KB di tanah air. Banyak anggota masyarakat tidak mampu membiayai pelayanan KB, membiayai ongkos transportasi ke klinik dan/atau membayar harga alat dan obat kontrasepsi (alokon). Pemerintah kesulitan menyelenggarakan pelayanan KB dan/atau menyediakan alokon bersubsidi atau gratis, sehingga banyak pasangan usia subur (PUS) yang drop out. 1

Tahun 2002, implementasi kebijakan desentralisasi

Alamat Korespondensi: Besral, Departemen Biostatistik dan Ilmu Kependudukan FKM Universitas Indonesia Gd. A Lt. 2 Kampus Baru UI Depok 16424, Hp.085880984413, e-mail: besral@yahoo.com 
mengakibatkan kegiatan koordinisasi yang sebelumnya menjadi tanggung jawab BKKBN terhambat. Kegiatan tersebut antara lain meliputi pengadaan alat dan obat kontrasepsi (alokon), kegiatan komunikasi informasi dan edukasi (KIE), program pendidikan dan pelatihan tenaga pelaksana KB (diklat), serta sistem informasi KB. Hal tersebut terjadi akibat prioritas dan kebijakan di berbagai daerah yang berbeda. 2,3

Pelayanan KB merupakan salah satu pelayanan kesehatan dasar, sehingga Kementerian Kesehatan menetapkan KB sebagai salah satu program kesehatan wajib yang harus disukseskan. Pelayanan kontrasepsi masuk dalam daftar standar pelayanan minimal (SPM) yang harus dilaksanakan dan menjadi tanggung jawab seluruh jajaran kesehatan di Indonesia. ${ }^{4,5}$ Kementerian Kesehatan mengembangkan model sistem informasi KB-kesehatan yang telah disosialisasikan sejak tahun 2007. Penelitian ini bertujuan mengkaji efisiensi dan efektivitas sistem informasi KB-kesehatan tersebut dibandingkan dengan sistem informasi sebelumnya.

\section{Metode}

Desain penelitian yang dipergunakan pada penelitian ini adalah desain cross-sectional. Desain ini dilakukan pada satu waktu tertentu terhadap puskesmas yang telah melaksakan sistem informasi KB-kesehatan tanpa pemantauan. Penelitian dilakukan di empat provinsi, meliputi DKI Jakarta, Lampung, Kalimatan Tengah, dan Bali. Di tiap provinsi dipilih dua kabupaten/kota dan pada tiap kabupaten/kota dipilih dua puskesmas yang telah menerapkan sistem informasi KB-kesehatan. Secara keseluruhan diteliti 16 puskesmas, delapan dinas kesehatan, dan empat provinsi. 6 Pengumpulan data dilakukan pada bulan Juni-September 2008. Populasi adalah seluruh puskemas milik pemerintah dan pemerintah daerah yang menyelenggarakan pelayanan kontrasepsi dan atau program KB di Indonesia beserta petugas pelayanannya. Sampel adalah 63 orang responden di puskemas terpilih, di kabupaten/kota, dan di provinsi. Pemilihan sampel dilakukan secara acak di wilayah penelitian. ${ }^{7}$

Pengumpulan data dilakukan dengan wawancara terstruktur menggunakan daftar pertanyaan yang telah disiapkan. Pengumpulan data dilakukan oleh peneliti dibantu oleh dua orang petugas yang sudah dilatih tentang sistem infromasi KB-kesehatan dan prosedur pelaksanaan penelitian. Variabel penelitian, terdiri dari variabel terikat efisiensi dan efektivitas. Efisiansi adalah persepsi responden terhadap efisiensi sistem informasi KB-kesehatan yang baru dikembangkan dan efektivitas adalah persepsi responden terhadap efektivitas sistem informasi KB-kesehatan yang baru dikembangkan. Variabel bebas meliputi wilayah, lingkup kerja, dan jabatan. Wilayah meliputi empat provinsi terpilih yang menyelenggarakan sistem infor- masi KB-kesehatan yang baru dikembangkan. Lingkup kerja adalah lingkup pekerjaan responden yang meliputi dinas kesehatan provinsi, dinas kesehatan kabupaten/kota, dan puskesmas. Jabatan adalah jabatan responden meliputi kepala subdinas, kepala seksi di provinsi/kabupaten-kota, koordinator program, kepala puskesmas, dan bidan koordinator.

Pengolahan data dilakukan dengan bantuan perangkat lunak komputer untuk pengolahan data SPSS. Uji data statistik dilakukan secara berjenjang meliputi analisis univariat dan analisis bivariat. Analisis univariat bertujuan mengetahui frekuensi dan distribusi variabel yang diteliti dengan nilai statistik deskriptif meliputi nilai tengah (mean) dan nilai penyebaran. Analisis bivariat dilakukan untuk mengetahui hubungan antara pelbagai variabel bebas dengan variabel terikat. Uji statistik yang dipergunakan adalah uji Anova untuk data numerik lebih dari dua kelompok dan uji Kruskal-Wallis untuk data yang tidak berdistribusi normal dengan tingkat kemaknaan pada $(\alpha=5 \%) .8,9$

\section{Hasil}

\section{Karakteristik Responden}

Sebaran responden yang berpartisipasi dalam studi ini beragam, paling sedikit berasal dari Provinsi DKI Jakarta (19\%) dan terbanyak berasal dari Provinsi Kalimantan Tengah (28\%). Lingkup kerja responden juga beragam meliputi dinas kesehatan provinsi sebanyak $(17,5 \%)$, dinas kesehatan kabupaten $(25,4 \%)$, dan yang terbanyak berasal dari puskesmas $(57,1 \%)$.

\section{Efektivitas Sistem Informasi KB}

Sebagian besar responden menyatakan bahwa sistem informasi KB yang baru dikembangkan tersebut lebih efektif. Sebagian besar jawaban responden mengelompok pada kategori lebih efektif atau sangat lebih efektif, walaupun ada yang menjawab sama efektif atau kurang efektif, tetapi dengan proporsi yang relatif kecil. Secara keseluruhan, empat dari lima responden $(77,8 \%)$ berpendapat bahwa sistem informasi KB yang baru lebih efektif atau sangat lebih efektif dibandingkan dengan sistem yang lama. Masih ada seperlima responden yang berpendapat sama atau kurang efektif (Lihat Tabel 1).

\section{Persepsi tentang Efisiensi Sistem Informasi KB}

Sistem informasi KB yang baru dikembangkan tersebut lebih efisien daripada sistem yang lama, jawaban responden sebagian besar mengelompok pada jawaban lebih efisien atau sangat lebih efisien. Walaupun ada yang menjawab sama efisien atau kurang efisien, tetapi dengan proporsi yang kecil. Proporsi yang menyatakan sistem yang baru sama efisien dengan sistem lama bervariasi pada kisaran 17,5 - 30\% yang hampir merata di setiap komponen informasi yang merujuk indikator KB yang lama 
Tabel 1. Persepsi Responden terhadap Efektivitas Sistem Informasi KB Kesehatan yang Baru

\begin{tabular}{|c|c|c|c|c|c|}
\hline \multirow{2}{*}{ Komponen yang Diamati } & \multicolumn{5}{|c|}{ Katagori Efektivitas (\%) } \\
\hline & Sangat kurang & Kurang & Sama & Lebih & Sangat Lebih \\
\hline Jumlah PUS gakin & - & 6,3 & 12,7 & 63,5 & 17,5 \\
\hline Jumlah PUS gakin ber-KB & - & 4,8 & 14,3 & 66,7 & 14,3 \\
\hline Jumlah PUS 4T & - & 1,6 & 22,2 & 57,1 & 19,0 \\
\hline Jumlah PUS 4T ber-KB & - & 4,8 & 23,8 & 52,4 & 19,0 \\
\hline Jumlah PUS anemia & - & 3,2 & 25,4 & 52,4 & 19,0 \\
\hline Jumlah PUS anemia ber-KB & - & 7,9 & 22,2 & 55,6 & 14,3 \\
\hline Jumlah PUS penyakit kronis & - & 6,3 & 20,6 & 58,7 & 14,3 \\
\hline Jumlah PUS penyakit kronis ber-KB & - & 6,3 & 20,6 & 58,7 & 14,3 \\
\hline Jumlah PUS LILA $<23,5$ & - & 12,7 & 20,6 & 44,4 & 22,2 \\
\hline Jumlah PUS LILA < 23,5 ber-KB & - & 12,7 & 25,4 & 46,0 & 15,9 \\
\hline Proporsi KB baru & - & 3,2 & 19,0 & 60,3 & 17,5 \\
\hline Proporsi KB aktif & - & 6,3 & 17,5 & 58,7 & 17,5 \\
\hline Proporsi komplikasi & - & 6,3 & 15,9 & 60,3 & 17,5 \\
\hline Proporsi kegagalan & - & 6,3 & 22,2 & 55,6 & 15,9 \\
\hline Proporsi efek samping & - & 6,3 & 22,2 & 58,7 & 12,7 \\
\hline Proporsi drop out KB & - & 6,3 & 19,0 & 57,1 & 17,5 \\
\hline Proporsi KB pasca salin/aborsi & - & 6,3 & 15,9 & 65,1 & 12,7 \\
\hline Tabel PWS-KB & - & 9,5 & 22,2 & 52.4 & 15,9 \\
\hline Grafik PWS KB & 1,6 & 12,7 & 23,8 & 47,6 & 14,3 \\
\hline Total & & \multicolumn{2}{|c|}{22,2} & \multicolumn{2}{|c|}{$77,8^{*}$} \\
\hline
\end{tabular}

*Gabungan jawaban lebih efektif dan sangat lebih efektif

Tabel 2. Persepsi Efisiensi Sistem Informasi KB yang Baru

\begin{tabular}{|c|c|c|c|c|c|}
\hline \multirow{2}{*}{ Komponen yang Diamati } & \multicolumn{5}{|c|}{ Katagori Efisien (\%) } \\
\hline & Sangat kurang & Kurang & Sama & Lebih & Sangat Lebih \\
\hline Jumlah PUS gakin & - & 11,1 & 17,5 & 57,1 & 14,3 \\
\hline Jumlah PUS gakin ber-KB & - & 9,5 & 25,4 & 52,4 & 12,7 \\
\hline Jumlah PUS 4T & - & 12,7 & 20,6 & 50,8 & 15,9 \\
\hline Jumlah PUS 4T ber-KB & - & 11,1 & 27,0 & 42,9 & 19,0 \\
\hline Jumlah PUS anemia & - & 9,5 & 25,4 & 47,6 & 17,5 \\
\hline Jumlah PUS anemia ber-KB & - & 12,7 & 23,8 & 47,6 & 15,9 \\
\hline Jumlah PUS penyakit kronis & - & 9,5 & 30,2 & 46,0 & 14,3 \\
\hline Jumlah PUS penyakit kronis ber-KB & - & 6,3 & 23,8 & 58,7 & 11,1 \\
\hline Jumlah PUS LILA $<23,5$ & - & 11,1 & 25,4 & 46,0 & 17,5 \\
\hline Jumlah PUS LILA $<23,5$ ber-KB & - & 12,7 & 25,4 & 46,0 & 15,9 \\
\hline Proporsi KB baru & - & 6,3 & 20,6 & 54,0 & 19,0 \\
\hline Proporsi KB aktif & - & 11,1 & 17,5 & 54,0 & 17,5 \\
\hline Proporsi komplikasi & - & 11,1 & 22,2 & 49,2 & 17,5 \\
\hline Proporsi kegagalan & - & 14,3 & 20,6 & 50,8 & 14,3 \\
\hline Proporsi efek samping & - & 7,9 & 25,4 & 54,0 & 12,7 \\
\hline Proporsi drop out KB & - & 7,9 & 23,8 & 50,8 & 17,5 \\
\hline Proporsi KB pasca salin/aborsi & - & 9,5 & 22,2 & 54,0 & 14,3 \\
\hline Tabel PWS-KB & - & 11,1 & 23,8 & 49,2 & 15,9 \\
\hline Grafik PWS KB & 1,6 & 15,9 & 23,8 & 42,9 & 15,9 \\
\hline Total & & & & & \\
\hline
\end{tabular}

*Gabungan jawaban lebih efisien dan sangat lebih efisien

dan yang baru. Hal tersebut mengindikasikan bahwa sistem informasi yang baru masih perlu perbaikan. Secara keseluruhan, dua per tiga responden berpendapat bahwa sistem informasi KB yang baru lebih atau sangat efisien daripada sistem yang lama (Lihat Tabel 2).

\section{Skor Persepsi Efektivitas dan Efisiensi}

Setiap komponen efektivitas dan efisiensi sistem in- formasi KB mempunyai 19 komponen yang diberi skor 1 untuk sangat kurang, 2 untuk kurang, 3 untuk sama saja, 4 untuk lebih, dan 5 untuk sangat lebih. Skor tersebut dijumlahkan dan untuk memudahkan membaca skor dan membuat perbandingan skor total, skor maksimum dijadikan 100 dengan cara mengalikan dengan 100/95. Skor efektivitas dan efisiensi ditampilkan pada Tabel 3. Skor persepsi efektivitas dan efisiensi sistem informasi 
Tabel 3. Rata-rata Skor Persepsi Responden terhadap Efektivitas dan Efisiensi Sistem Informasi KB

\begin{tabular}{lccccccc}
\hline \multirow{2}{*}{ Persepsi } & \multicolumn{7}{c}{ Skor } \\
\cline { 2 - 7 } & $\mathbf{n}$ & Min & Maks & Mean & Median & SD & 95\% CI mean \\
\hline Efektivitas sistem informasi KB & 63 & 46 & 100 & 76,4 & 77,8 & 12,9 & $73,2-79,7$ \\
Efisiensi sistem informasi KB & 63 & 40 & 100 & 74,2 & 77,8 & 14.9 & $70,4-77,9$ \\
Rerata Persepsi & 63 & 44 & 100 & 75,3 & 77,8 & 13,5 & $71,9-78,7$ \\
\hline
\end{tabular}

Tabel 4. Perbedaan Skor Efektivitas dan Efisiensi Sistem Informasi KB Menurut Provinsi

\begin{tabular}{|c|c|c|c|c|c|c|c|c|}
\hline \multirow{3}{*}{ Provinsi } & \multicolumn{8}{|c|}{ Skor Persepsi terhadap Efektivitas } \\
\hline & \multirow[t]{2}{*}{$\mathbf{n}$} & \multirow[t]{2}{*}{ Mean } & \multirow[t]{2}{*}{ Std. Dev } & \multicolumn{2}{|c|}{ 95\% IK untuk Mean } & \multirow[t]{2}{*}{ Min } & \multirow[t]{2}{*}{ Maks } & \multirow{2}{*}{$\begin{array}{l}\text { Nilai-p } \\
\text { Anova }\end{array}$} \\
\hline & & & & Batas Bawah & Batas Atas & & & \\
\hline DKI & 12 & 77,6 & 18,1 & 66,1 & 89,1 & 56 & 100 & \\
\hline Bali & 16 & 68,9 & 9,7 & 63,7 & 74,1 & 46 & 80 & \\
\hline Lampung & 17 & 76,0 & 11,1 & 70,3 & 81,8 & 55 & 96 & 0,017 \\
\hline \multirow[t]{2}{*}{ Kalteng } & 18 & 82,7 & 10,1 & 77,7 & 87,7 & 59 & 98 & \\
\hline & \multicolumn{7}{|c|}{ Skor Persepsi terhadap Efisiensi } & \\
\hline DKI & 12 & 76,3 & 19,7 & 63,8 & 88,8 & 48 & 100 & \\
\hline Bali & 16 & 61,3 & 11,8 & 55,0 & 63,6 & 40 & 80 & \\
\hline Lampung & 17 & 76,2 & 11,2 & 70,5 & 82,0 & 55 & 100 & 0,000 \\
\hline Kalteng & 18 & 82,2 & 9,6 & 77,4 & 87,0 & 59 & 97 & \\
\hline
\end{tabular}

$\mathrm{IK}=$ interval konfidens, Min $=$ minimum, Maks $=$ maksimum, std. dev $=$ standar deviasi

KB yang baru dibandingkan dengan sistem yang lama cukup tinggi. Rata-rata skor efektivitas ditemukan 76,4 dan rata-rata skor efisiensi ditemukan 74,2. Skor efektivitas terentang pada kisaran 46 sampai 100 , sedangkan skor efisiensi berkisar antara 40 sampai 100 (Lihat Tabel 3).

\section{Perbedaan Skor Efektivitas dan Efisiensi Menurut Provinsi}

Untuk mengetahui lebih jauh komponen yang perlu diperbaiki, meliputi provinsi yang perlu penanganan lebih lanjut dan perbedaan skor antar provinsi, kabupaten, dan puskesmas. Untuk itu, perlu dilakukan analisis lebih rinci tentang perbedaan skor efektivitas dan efisiensi sistem informasi KB. Skor efektivitas antarprovinsi berbeda secara bermakna (nilai $\mathrm{p}=0,017)$. Skor efektivitas tertinggi di Provinsi Kalimantan Tengah $(82,7)$ dan skor terendah di Provinsi Bali $(68,9)$. Uji perbandingan ganda (multiple comparisons) memperlihatkan bahwa yang berbeda bermakna hanya Provinsi Kalimantan Tengah dengan Provinsi Bali saja. Dengan demikian, efektivitas sistem informasi KB dipersepsikan berbeda antar provinsi di Indonesia, tidak semua provinsi mempunyai keyakinan yang sama tentang efektivitas sistem informasi untuk menjawab kebutuhan informasi (Lihat Tabel 4).
Perbedaan Skor Efektivitas dan Efisiensi Menurut Lingkup Kerja

Skor efektivitas sistem informasi KB yang baru berdasarkan lingkup kerja yang tertinggi ditemukan di dinas kesehatan provinsi $(80,2)$, sementara skor untuk kabupaten dan puskesmas hampir sama (75). Perbedaan itu mungkin terjadi secara kebetulan (nilai $\mathrm{p}=0,573$ ). Temuan yang sama terlihat pada efisiensi, skor tertinggi ditemukan di dinas kesehatan provinsi $(79,6)$, sedangkan statistik (nilai $\mathrm{p}=0,417$ ) (Lihat Tabel 5).

Perbedaan skor efektivitas sistem informasi KB menurut lingkup kerja secara statistik tidak bermakna (nilai $\mathrm{p}$ $=0,573)$. Sistem informasi KB yang baru cukup efisien menjawab kebutuhan informasi KB daripada sistem yang lama, yang terlihat pada rata-rata skor persepsi efektivitas tinggi (rata-rata skor 70,5).

\section{Perbedaan Skor Efektivitas dan Efisiensi Menurut Jabatan}

Perbandingan efektivitas sistem informasi KB yang baru dan yang lama memperlihatkan variasi skor berdasarkan jabatan. Skor rata-rata tertinggi adalah kepala seksi yang membawahi program KB di dinas kesehatan provinsi $(83,4)$ dan skor rata-rata terendah kepala seksi di kabupaten $(67,2)$, tetapi perbedaan tersebut secara statistik tidak bermakna (nilai $p=0,565$ ). Hal yang sama terlihat pada skor efisiensi yang bervariasi 
Tabel 5. Perbedaan Skor Efektivitas dan Efisiensi Sistem Informasi KB Menurut Lingkup Kerja Responden

\begin{tabular}{|c|c|c|c|c|c|c|c|c|}
\hline \multirow{3}{*}{ Lingkup Kerja } & \multicolumn{8}{|c|}{ Skor Persepsi terhadap Efektivitas SI KB yang Baru } \\
\hline & \multirow[t]{2}{*}{ n } & \multirow[t]{2}{*}{ Mean } & \multirow[t]{2}{*}{ Std. Dev } & \multicolumn{2}{|c|}{ 95\% IK untuk Mean } & \multirow[t]{2}{*}{ Min } & \multirow[t]{2}{*}{ Max } & \multirow{2}{*}{$\begin{array}{l}\text { Nilai } p \\
\text { Anova }\end{array}$} \\
\hline & & & & Batas Bawah & Batas Atas & & & \\
\hline Dinas propinsi & 11 & 80,2 & 10,4 & 73,2 & 87,2 & 67 & 97 & \\
\hline Dinas kabupaten & 16 & 75,9 & 13,2 & 68,9 & 83,0 & 57 & 96 & 0,573 \\
\hline \multirow[t]{2}{*}{ Puskesmas } & 36 & 75,5 & 13,6 & 70,9 & 80,1 & 46 & 100 & \\
\hline & \multicolumn{8}{|c|}{ Skor Persepsi terhadap Efisiensi SI KB yang baru } \\
\hline Dinas propinsi & 11 & 79,6 & 12,6 & 71,2 & 88,1 & 61 & 100 & \\
\hline Dinas kabupaten & 16 & 72,7 & 15,4 & 64,5 & 80,9 & 43 & 96 & 0,417 \\
\hline Puskesmas & 36 & 73,2 & 15,4 & 67,9 & 78,4 & 40 & 100 & \\
\hline
\end{tabular}

$\mathrm{IK}=$ interval konfidens. Anova $=$ Analysis of Variance

Tabel 6. Perbedaan Skor Efektifitas dan Efisiensi Sistem Informasi KB Menurut Jabatan Responden

\begin{tabular}{|c|c|c|c|c|c|c|c|c|}
\hline \multirow[t]{3}{*}{ Jabatan } & \multicolumn{8}{|c|}{ Skor Persepsi terhadap Efektifitas SI KB yang Baru } \\
\hline & \multirow[t]{2}{*}{$\mathbf{n}$} & \multirow[t]{2}{*}{ Mean } & \multirow[t]{2}{*}{ Std. Dev } & \multicolumn{2}{|c|}{ 95\% CI untuk Mean } & \multirow[t]{2}{*}{ Min } & \multirow[t]{2}{*}{ Max } & \multirow{2}{*}{$\begin{array}{c}\text { Nilai p } \\
\text { KW }\end{array}$} \\
\hline & & & & Batas Bawah & Batas Atas & & & \\
\hline Propinsi: Kasubdin & 2 & 75,3 & 6,7 & 15,1 & 135,5 & 71 & 80 & \\
\hline Propinsi: Kasie & 4 & 83,4 & 12,4 & 63,7 & 103,1 & 67 & 94 & \\
\hline Propinsi: $\mathrm{Pj}$ program $\mathrm{KB}$ & 5 & 79,6 & 11,1 & 65,9 & 93,3 & 68 & 97 & 0,565 \\
\hline Kab Kasubdin & 6 & 79,5 & 14,9 & 63,8 & 95,1 & 60 & 96 & \\
\hline Kab Kasie & 5 & 67,2 & 10,9 & 53,6 & 80,8 & 57 & 80 & \\
\hline Kab $\mathrm{Pj}$ program $\mathrm{KB}$ & 5 & 80,4 & 10,7 & 67,2 & 93,7 & 65 & 95 & \\
\hline Kepala puskesmas & 12 & 77,4 & 16,7 & 66,7 & 88,0 & 46 & 100 & \\
\hline \multirow[t]{2}{*}{ Bidan koordinator/desa } & 24 & 74,6 & 12,1 & 69,5 & 79,7 & 55 & 100 & \\
\hline & \multicolumn{8}{|c|}{ Skor Persepsi terhadap Efisiensi SI KB yang Baru } \\
\hline Propinsi: Kasubdin & 2 & 75,3 & 6,7 & 15,1 & 135,5 & 71 & 80 & \\
\hline Propinsi: Kasie & 4 & 85,0 & 13,8 & 63,1 & 106,9 & 68 & 100 & \\
\hline Propinsi: $\mathrm{Pj}$ program KB & 5 & 77,1 & 14,0 & 59,6 & 94,5 & 61 & 97 & 0,314 \\
\hline Kab Kasubdin & 6 & 77,5 & 13,2 & 63,7 & 91,4 & 60 & 95 & \\
\hline Kab Kasie & 5 & 59,2 & 14,4 & 41,3 & 77,0 & 43 & 80 & \\
\hline Kab $\mathrm{Pj}$ program $\mathrm{KB}$ & 5 & 80,4 & 11,4 & 66,3 & 94,6 & 64 & 96 & \\
\hline Kepala puskesmas & 12 & 75,2 & 17,4 & 64,1 & 86,2 & 43 & 100 & \\
\hline Bidan koordinator/desa & 24 & 72,1 & 14,6 & 66,0 & 78,3 & 40 & 100 & \\
\hline
\end{tabular}

KW = Kruskal Wallis (One way Anova)

skor menurut jabatan. Kepala seksi yang membawahi program KB di provinsi mempunyai rata-rata skor tertinggi (85) dan kepala seksi di kabupaten mempunyai rata-rata skor terendah (59), tetapi perbedaan tersebut secara statistik tidak bermakna (nilai $\mathrm{p}=0,314$ ).

\section{Pembahasan}

Hampir semua jabatan yang berhubungan dengan program KB telah tercakup dalam studi ini, walaupun belum menyebar secara merata, dari aspek keragaman telah mewakili semua jabatan. Jabatan tertinggi yang menjadi sumber informasi studi ini adalah kepala subdinas yang membawahi program KB di tingkat provinsi dua orang, diikuti oleh kepala seksi yang membawahi program KB di tingkat provinsi empat orang, dan penanggung jawab program KB di tingkat provinsi lima orang. Sebagian besar jabatan responden adalah bidan koordinator atau bidan di desa sebanyak 38\% dan kepala puskesmas sebanyak 19\%.

Proporsi responden yang menyatakan bahwa sistem informasi KB yang baru dikembangkan sama efektif dengan sistem yang lama cukup bervariasi dari $12-25 \%$. Angka ini hampir merata pada setiap komponen informasi $\mathrm{KB}$, pada komponen yang merujuk pada indikator KB yang lama dan pada yang baru. Hal ini mengindikasikan bahwa sistem informasi yang baru masih 
memerlukan perbaikan pada berbagai komponen. Informasi lain yang didapat pada saat diskusi mendalam dengan beberapa responden terkait dengan perbaikan yang perlu dilakukan pada sistem informasi KB yang baru ini adalah bahwa pentingnya penyediaan formulir, penyediaan tenaga, dan prasarana terkait sistem informasi KB yang selama ini juga sudah menjadi masalah.

Komponen tertinggi yang diragukan responden adalah pada komponen Grafik PWS (Pemantauan Wilayah Setempat) KB. Pada sistem yang baru dikembangkan ini, komponen pembuatan grafik PWS KB belum sepenuhnya dikerjakan secara komputerisasi, karena belum ada pelatihan khusus. Akibatnya, responden harus membuat grafik PWS KB secara manual, yang dirasakan sangat tidak efektif dan rawan terhadap kesalahan perhitungan. Dalam pengembangan selanjutnya, disarankan agar sistem informasi KB ini juga dilengkapi grafik PWS $\mathrm{KB}$ dengan komputerisasi, sehingga meminimalkan kesalahan akibat kesalahan perhitungan secara manual, dan sekaligus mempercepat proses pengolahan dan analisis data. Jumlah PUS dengan lingkar lengan atas (LILA) kurang dari $23,5 \mathrm{~cm}$ yang ber-KB juga diragukan efektif. Berdasarkan hasil penelusuran dengan metode diskusi kelompok didapatkan informasi bahwa responden kesulitan mendapatkan data LILA karena ketika uji coba, sistem informasi ini tidak dilengkapi dengan sarana dan pendukung untuk pengukuran LILA.

Penelusuran melalui diskusi kelompok didapatkan penjelasan bahwa sistem informasi KB yang baru dikembangkan ini dirasakan menambah beban petugas di lapangan. Sejak tahun 1997, petugas KB di lapangan tidak pernah membuat laporan tentang $\mathrm{KB}$, karena sistem pencatatan dan pelaporan KB telah dilimpahkan kepada BKKBN. Sehubungan dengan restrukturisasi organisasi, organisasi BKKN bervariasi organisasi antara wilayah, sehingga banyak informasi KB yang tidak tersedia di kabupaten. Sekarang, Kementerian Kesehatan RI mengembangkan sistem informasi KB baru, yang akan diberlakukan secara nasional yang secara otomatis menjadi pekerjaan tambahan pelaksana program di lapangan. Namun, pekerjaan tambahan tersebut akan menjadi sangat bermanfaat bagi perencanaan dan evalusi program KB di tingkat kabupaten/kota, provinsi, dan bahkan bagi Kementerian Kesehatan.

Ada perbedaan skor efisiensi sistem informasi KB menurut lingkup kerja, namun perbedaan ini tidak bermakna secara statistik (nilai $p=0,417$ ). Secara umum dapat dikatakan bahwa sistem informasi KB yang baru dikembangkan lebih efisiensi dibandingkan dengan sistem yang lama, hal ini dirasakan oleh semua staf yang bekerja di tiap tingkatan, mulai dari tingkat puskesmas, dinas kesehatan kabupaten/kota, sampai ke pimpinan di dinas kesehatan provinsi. Skor efisiensi sangat bervariasi antarpropinsi dan variasi itu bermakna secara statistik (ni- lai $\mathrm{p}=0,000$ ). Skor tertinggi efisiensi ada di Provinsi Kalimantan Tengah yakni 82 dan skor terendah ada di Provinsi Bali yakni 61,3. Hasil uji perbandingan ganda (multiple comparisons) memperlihatkan bahwa yang berbeda bermakna adalah Provinsi Bali dengan ketiga provinsi lainnya (Kalimantan Tengah, DKI Jakarta, dan Lampung, output tidak ditampilkan). Dengan demikian, dapat disimpulkan bahwa efisiensi sistem informasi $\mathrm{KB}$ dipersepsikan berbeda-beda antar provinsi di Indonesia, provinsi Bali tidak begitu yakin akan efisiensi sistem informasi $\mathrm{KB}$ yang baru dikembangkan untuk menjawab kebutuhan informasi KB. Secara umum dapat disimpulkan bahwa sistem informasi KB yang baru dikembangkan lebih efektif dan lebih efisien dibandingkan dengan sistem yang lama, dan pendapat ini dipersepsikan sama oleh semua staf di semua tingkatan, baik yang bekerja di puskesmas, dinas kesehatan kabupaten/kota, maupun oleh pimpinan mereka di dinas kesehatan provinsi.

Aspek jabatan terlihat bahwa responden mempunyai persepsi yang sama terhadap efektivitas dan efisiensi sistem informasi $\mathrm{KB}$ yang baru dikembangkan untuk menjawab kebutuhan informasi KB. Kesamaan persepsi ini dirasakan oleh semua dari jajaran yang paling rendah (bidan di desa/bidan koordinator), kepala puskesmas, sampai ke penanggung jawab program dan kepala seksi ataupun kepala subdinas di tingkat kabupaten/kota atau provinsi.

\section{Kesimpulan}

Efektivitas dan efisiensi sistem informasi KB yang baru cukup baik, 77,8\% responden menyatakan lebih efektif atau sangat lebih efektif dan $66,7 \%$ responden menyatakan lebih efisiensi atau sangat lebih efisien dibandingkan dengan sistem yang lama. Skor efektivitas dan efisiensi bervariasi antarprovinsi dan perbedaan itu bermakna secara statistik (nilai $\mathrm{p}<0,001$ ), dimana Provinsi Bali memiliki rata-rata skor terendah $(68,9$ untuk efektivitas dan 61,3 untuk efisiensi), dan Kalimantan Tengah memiliki skor tertinggi (82,7 untuk efektivitas dan 82,2 untuk efisiensi). Ada perbedaan skor efektivitas dan efisiensi sistem informasi KB menurut lingkup kerja dan jabatan responden, namun perbedaan ini tidak bermakna secara statistik (nilai p lebih besar dari alpha 5\%). Artinya efektivitas dan efisiensi sistem informasi KB yang baru dikembangkan dirasakan sama oleh semua staf yang bekerja di semua tingkatan (mulai dari tingkat puskesmas, dinas kesehatan kabupaten/kota, sampai ke pimpinan di dinas kesehatan provinsi).

\section{Saran}

Disarankan kepada Kementerian Kesehatan untuk melakukan perbaikan pada komponen sistem informasi keluarga berencana terutama pada komponen pelaporan 
dan pembuatan grafik PWS KIA dan mengimplementasikan di pelayanan KB di puskemas dan jaringannya. Selain itu, implementasi sistem informasi KB ini hendaklah dilengkapi dengan prasarana untuk mengukur lingkar lengan atas dari PUS yang mendapatkan pelayanan.

\section{Daftar Pustaka}

1. BKKBN. Evaluasi program KB nasional tahun 2005-2007. Dalam Rapat Kerja Program KB Nasional Tahun 2008. Jakarta: BKKBN; 2008.

2. BKKBN. Kebijakan dan strategi operasional pencapaian sasaran tahun 2008 2009. Dalam Rapat Kerja Program KB Nasional tahun 2008. Jakarta: BKKBN; 2008.

3. Marbun BN. Masa depan otonomi daerah di Indonesia. Otonomi daerah
1945-2005, proses dan realita: perkembangan Otda sejak zaman kolonial sampai saat ini. Jakarta: Pustaka Sinar Harapan; 2005. h.10-45.

4. Kementrian Kesehatan RI. Standar pelayanan minimal bidang kesehatan di kabupaten/kota. Jakarta: Kementrian Kesehatan RI; 2003.

5. Kementrian Kesehatan RI dan UNFPA. Analisis situasi dan bimbingan teknis pengelolaan pelayanan KB. Jakarta: Kementrian Kesehatan RI; 2005.

6. Ryan TP. Satistical methods for quality improvement. New York: John Wiley \& Sons; 1989.

7. Dahlan MS, Besar. Sampel dan cara pengambilan sampel dalam penelitian kedokteran dan kesehatan. Jakarta: Salemba Medika; 2009.

8. Dahlan MS. Statistik untuk kedokteran kesehatan. Jakarta: Salemba Medika; 2009

9. Sheskin D. Handbook of parametric and non parametric statistical procedures. Washington DC: Chapman \& Hall/CRC Press Company; 2004. 